\title{
Resilience response to yellow leaf curl disease and identification of resistance gene analogs (RGA) in pepper (Capsicum annuum)
}

\author{
DYAN KUSUMANING AYU ${ }^{1, \bullet}$, AWANG MAHARIJAYA ${ }^{2,3, v \bullet}$, MUHAMAD SYUKUR ${ }^{2,3}$, \\ SRI HENDRASTUTI HIDAYAT ${ }^{4}$ \\ ${ }^{1}$ Program of Plant Breeding and Biotechnology, Graduate School, Institut Pertanian Bogor. Jl. Raya Dramaga, Kampus IPB Dramaga, Bogor 16680, \\ West Java, Indonesia. `email: adyankusuma@gmail.com \\ ${ }^{2}$ Departement of Agronomy and Horticulture, Faculty of Agriculture, Institut Pertanian Bogor. Jl. Meranti, Kampus IPB Darmaga, Bogor 16680, West \\ Java, Indonesia. Tel./fax.: +62-251-8629353.`^email: awang.maharijaya@gmail.com \\ ${ }^{3}$ Center for Tropical Horticulture Studies, Institut Pertanian Bogor. Jl. Raya Pajajaran, Kampus IPB Baranangsiang, Bogor 16153, West Java, Indonesia \\ ${ }^{4}$ Departement of Plant Protection, Faculty of Agriculture, Institut Pertanian Bogor. Jl. Meranti, Kampus IPB Darmaga, Bogor 16680, Indonesia
}

Manuscript received: 14 July 2021. Revision accepted: 11 October 2021.

\begin{abstract}
Ayu DK, Maharijaya A, Syukur M, Hidayat SH. 2021. Resilience response to yellow leaf curl disease and identification of resistance gene analogs (RGA) in pepper (Capsicum annuum). Biodiversitas 22: 4731-4739. Pepper yellow leaf curl disease (PYLCD) caused by infection of Begomovirus is a serious threat to pepper production worldwide. Identification of the resistance gene analogs (RGA) and resilience response of pepper against PYLCD is needed especially for selection resistance genotype. Evaluation of resistance response involving 28 pepper genotypes was carried out through transmission of Begomovirus using whitefly (Bemisia tabaci) as vector. The result showed that IPB C12 and F4-012328-6-3 were potential resistance genotypes. A total of 15 R gene analogs (CaRGA) containing NBS motif, namely CARGA1 to CARGA15, were identified by degenerated PCR amplification and database mining. The alignment of deduced amino acid sequence revealed conservation of subdomains Ploop (GKTT), kinase2 (LVVLDDV), RNBSB/kinase3 (IILTTR) and GLPL. BLASTp analysis indicated that 15 RGA showed high homology at deduced amino acid level with R gene identified such as whitefly resistance protein Mi-1.2, Pvr 9 gene for potyvirus, Begomovirus resistance protein, TRGA15 and RGA 13 for putative late blight resistance. Phylogenetic analysis exhibited that isolated sequences distinguished into CNL-NBS groups. These pepper RGA could be considered as candidate sequences of resistance genes.
\end{abstract}

Keywords: Begomovirus, degenerate primer, pepper, phylogenetic analysis, whitefly

\section{INTRODUCTION}

Pepper (Capsicum) is one of the most important vegetables in the world (Olatunji et al. 2018; Tripodi et al. 2019). The main constraint of pepper productivity is pests and diseases. Pepper yellow leaf curl disease (PYLCD) caused by Begomovirus is an important disease of pepper that has been reported in several countries (Koeda et al. 2018; Fadhila et al. 2020). Begomovirus was transmitted by the whitefly vector has led to the development and spread of PYLCD epidemics (Islam et al. 2018). It has been reported to occur widely in Asia (Kenyon et al. 2014), Australia, China, Europe, Middle Eastern Countries (Alshihi 2019), Africa (Ouattara et al. 2020) and the Americas (Barboza et al. 2018). The incidence of PYLCD in Indonesia was first reported between 1994 and 1999 (De Barro et al. 2008). In Indonesia, the yield loss due to PYLCD ranges from 20 to 100\% (Annisaa et al. 2021).

The disease is transmitted by vector, i.e., whitefly Bemisia tabaci Genn (Firdaus et al. 2013; Wei et al. 2017; Pandey et al. 2021) in a persistent and circulative way. $B$. tabaci is a species of phloem-feeding insect belonging to the Aleyrodidae (Ellango et al. 2015; Milenovic et al. 2019). During feeding the virus is taken up by the whitefly, which takes about $24 \mathrm{hrs}$, and during a latency period that takes $4-24 \mathrm{hrs}$, it is transferred to the salivary gland and then during feeding ( $>24 \mathrm{hrs}$.) excreted with the saliva to infect new plants (Ghanim 2014). Management of begomoviruses has become a challenge due to the continuous evolution and the emergence of new strains. Currently, PYLCD problems are dealt with by combating its vector. However, B. tabaci has relatively high reproduction rate and a short life cycle, it has a rapid dispersal ability, high survival rate to climatic changes, and quickly develops resistance to pesticides that make it difficult to control (Gilbertson et al. 2015). Various attempts have been made to control this disease, including protecting plants using net screen, planting border crops, application of insecticides (Horowitz et al. 2011), and biological control (Calvo et al. 2009; Soesanto et al. 2020). However, this strategy has not succeeded in preventing the spread of the disease. The use of resistant cultivars is always recommended, but commercial pepper cultivars carrying resistance to PYLCD are not available yet.

Plants have resistant genes which have the potential to detect the onset of infection and further activate resistance mechanisms against pathogenic infections (Yang et al. 2021). Structurally, resistant genes have special characteristics indicated by presence of conserved amino acid motifs. The conserved amino acid motif allows the identification of resistant gene fragments in genome of plant through amplification using degenerate primers. 
These primers are designed based on sequences of DNA resistance genes from other plants, known as resistance gene analogs (RGA) (Naresh et al. 2017). One of the largest RGA classes that have been characterized is the Nucleotide Binding Site. The NBS region is important for ATP binding and hydrolysis, so it is believed to be involved in signal transduction triggered by pathogen infection. NBS receptor protein recognizes pathogen effector protein that produces transduction signals to stimulate the expression of defense against pathogens (Caplan et al. 2008).

Research has been done to identify NBS in various plants such as wheat, barley, and tomatoes (Kushwaha et al. 2015; Yamaguchi et al. 2018). However, the identification of NBS is far behind in pepper against PYLCD. The objective of this research is to identify the NBS gene in pepper related to PLYCD resistance, which might be further developed toward PYLCD resistance breeding in pepper.

\section{MATERIALS AND METHODS}

\section{Study area}

The pepper genotypes used in this experiment were obtained from a collection of Plant Breeding Laboratory, Department of Agronomy and Horticulture, IPB University (Table 1). All genotypes belonged to Capsicum annuum. Isolate of Pepper yellow leaf curl virus (PYLCV) was used as the initial inoculum and whiteflies (B. tabaci) colony was provided by Plant Virology Laboratory, Department of Plant Protection, IPB University. The isolates were maintained in pepper in a restricted screen house; whereas whiteflies were reared on cotton plants inside insect cages.

\section{Procedure}

\section{Resistance test of 28 pepper genotypes to PYLCD}

Virus transmission for resilience test was carried out by individual transmission method, using 10 whiteflies for each plant. Whiteflies were given $24 \mathrm{hrs}$ acquisition feeding period on PYLCV-infected plants and then transferred to test plants for $48 \mathrm{hrs}$ inoculation feeding period. The age of test plants at the time of transmission was 10 days after transplanting.

The experiment was designed using a randomized block design with genotype as the treatment. Each treatment was performed thrice, and each consisted of 30 plants. The following parameters were observed in infected plants: type of symptoms, incubation period, incidence, and severity of the disease. Symptoms were categorized on a relative scale of 0 to 4 . Then the resilience response was classified based on the disease severity (DS) i.e., $0-20 \%$, $>20-40 \%$, $>40-60 \%$, and $>60 \%$ as resistant, moderately resistant, susceptible, and very susceptible, respectively. Data were analyzed by ANOVA using SPSS version 15.0 and a further test was conducted using the Duncan test (alpha 0.05). Confirmation of Begomovirus was carried out by polymerase chain reaction (PCR) using two degenerate primers SPG1 (5'-CCCCK-GTGCGWRAATCCAT-3') and SPG2 primer (5'-ATCCVAAYWTYCAGGGAGCT3 ') with a target amplicon of $912 \mathrm{bp}$. DNA amplicons were sent to First Base company (Malaysia) for sequencing; then the sequence was analyzed using the Seq Trace 0.9.0 and Geneious software version 8.1.6 (Biomatters, USA).

\section{Isolation of Nucleotide Binding Site (NBS)}

A pair of degenerate primers, previously designed based on conserved domains (P-loop and GLPL regions) among known NBS-LRR R genes from other plant (Zhang et al. 2008), were used (Table 2). The amplification reaction was carried out in the PCR machine with the following program: pre-denaturation at $95{ }^{\circ} \mathrm{C}$ for $5 \mathrm{~min}$, followed by 35 cycles with denaturation at $94{ }^{\circ} \mathrm{C}$ for 45 sec, primer annealing at $55^{\circ} \mathrm{C}$ for $1 \mathrm{~min}$, and elongation of DNA at $72{ }^{\circ} \mathrm{C}$ for $1 \mathrm{~min}$. In the last stage, the PCR process was carried out at a final elongation at $72{ }^{\circ} \mathrm{C}$ for $10 \mathrm{~min}$. The amplification product was electrophoresed on $1.2 \%$ agarose gel, followed by staining with $\operatorname{EtBr}\left(0.5 \mathrm{mgL}^{-1}\right)$ and visualization using UV Transilluminator. The presence of NBS in the pepper sample was indicated by the amplification of the 500 bp DNA fragment. The targeted NBS DNA fragments were sent for sequencing.

Table 2. Degenerate primers used for amplification of nucleotide binding site fragment in pepper

\begin{tabular}{ccl}
\hline $\begin{array}{c}\text { Degenerate } \\
\text { Primers }\end{array}$ & \multicolumn{1}{c}{ Primer Sequence (5'-3') } & Reference \\
\hline Ploop-F2 & TGSSRGGHWYRGGBAAAACTAC & $\begin{array}{l}\text { Zhang et } \\
\text { al. (2008) }\end{array}$ \\
GLPL-R2 & HRCWARAGGVARCCCTYBACA & $\begin{array}{l}\text { Zhang et } \\
\text { al. (2008) }\end{array}$ \\
\hline
\end{tabular}

Table 1. List of pepper genotypes used in resistance evaluation against yellow leaf curl disease

\begin{tabular}{llll}
\hline Name of genotypes & & & \\
\hline IPBC2 & Ayesha & F4-012328-1AB-2 & F7-145174-9-3-1-5-3 \\
IPBC5 & Seloka & F4-012328-6-3 & F7-145291-14-9-3-12-1 \\
IPBC12 & Yuni & F3-74 x Hot Chilli & F7-145291-10-7-1-1-1-1 \\
Gada & SSP & F3-Elegance x 74-2 & F5-145291-14-9-3 \\
Bara & Anies & F3-74 x Biola & F7-1200005-141-16-2-9-4 \\
Genie & Ungara & F7-160291-4-13-9-8-1 & F7-1200005-120-7-1-7-8 \\
Giant & Seroja & F7-145293-19-8-3-113-1 & F7-1200005-141-16-3-5-4 \\
\hline
\end{tabular}




\section{Data analysis}

DNA sequences were analyzed using the Seq Trace 0.9.0 software. The sequences were then translated into amino acids using the Transeq tool from the EMBOSS software suite (http://www.ebi.ac.uk/Tools/st/emboss_transeq/). Peptide sequences with uninterrupted ORF were selected and used for further analysis in this study. Identity and similarity searches of nucleotide and amino acid sequences were performed using BLAST at the National Centre for Biotechnology Information (NCBI) database (http://www.ncbi.nlm.nih.gov/BLAST/). The deduced amino acid sequences of the RGA isolated from the pepper, with other related plant RGAs were aligned with Multiple Sequence Allignment (MUSCLE) method and used for phylogenetic tree construction using MEGA (Molecular Evolutionary Genetic Analysis).

\section{RESULTS AND DISCUSSION}

\section{Symptoms of disease in pepper plant}

Symptoms of the disease that appear on all genotypes of pepper plants observed in the greenhouse, included yellowing, curling, mosaics, and bending upward or downward (Figure 1), but the dwarf symptom was not found. Out of 28 genotypes, 22 genotypes, namely IPB C2, IPB C5, Bara, SSP, Gada, Seloka, Yuni, Ungara, Seroja, F4-012328-1AB-2, F4-012328-6-3, F3-74 x Hot Chilli, F3Elegance x 74-2, F3-74 x Biola, F7-145293-19-8-3-113-1, F7-145174-9-3-1-5-3, F7-145291-14-9-3-12-1, F5-14529114-9-3, F7-1200005-141-16-3-5-4, F7-1200005-141-16-29-4, and F7-1200005-120-7-1-7-8 showed severe symptoms as described earlier; while 6 other genotypes, namely IPB C12, Genie, Giant, Ayesha, F7-160291-4-139-8-1, and F7-145291-10-7-1-1-1-1 exhibited mild symptoms including only yellowing and curling of leaves.

\section{Confirmation of PYLCV in symptomatic plants}

DNA fragments of 912 bp were successfully amplified from 28 symptomatic leaf samples using SPG1/SPG2 primers. Results of sequencing analysis confirmed that the virus infecting tested plants in the greenhouse had $100 \%$ homology with the virus inoculum source. Furthermore, the viral isolates used as inoculum showed $94.23 \%$ and $96.67 \%$ homology with the Pepper yellow leaf curl Indonesian virus [Ageratum] DNA, DNA-A segment (AB267838), and Pepper yellow leaf curl Indonesia Talibeng virus 1 AC1 gene (LC381258), respectively.
Genotype response to yellow leaf curl disease in pepper

Symptoms of disease in all plants appeared between 528 days after inoculation (dai). The longest i.e.12-28 dai incubation period occurred in IPB C12; while the shortest incubation period i.e. 5-18 dai occurred in IPB C5 (Table 3 ). The results showed that there was high variability in the level of resistance to PYLCD among the genotypes tested. The large variations among genotypes indicated the possibility of selection for resistance to this disease. Statistical analysis showed that genotype treatment significantly affected the incidence and severity of yellow leaf curl disease (Table 3). Disease incidence ranged from $20.00 \%$ to $93.33 \%$, while disease severity ranged from $18.33 \%$ to $72.78 \%$. The observational results showed that the greater the percentage of disease incidence and the symptom score, the greater the magnitude of disease severity. Low incidence and severity of disease were found in IPB C12 and F4-012328-6-3.

\section{Isolation and sequence analysis of NBS fragments}

The degenerate primers were designed to amplify the area between the P-loop motif and GLPL from the NBS area. DNA fragments of 500 bp were successfully amplified and nucleotide sequences were obtained from 15 DNA fragments. Results of nucleotide (501 bp to $528 \mathrm{bp}$ in length) and deduced amino acid (166 to 177 amino acid) analysis revealed that 15 fragments namely, CARGA1, CARGA2, CARGA3, CARGA4, CARGA5, CARGA6, CARGA7, CARGA8, CARGA9, CARGA10, CARGA11, CARGA12, CARGA13, CARGA14, and CARGA15 were containing NBS regions.

CARGA1 showed the similar identity of $72.41 \%$ with whitefly resistance protein $\mathrm{Mi}-1.2$ [Solanum peruvianum]; CARGA2, CARGA6, CARGA7, CARGA8, CARGA13, CARGA14, CARGA15 had a similarity of $81.71 \%$, $83.53 \%, 87.57 \%, 79.44 \%, 76.74 \%, 92.05 \%$, and $86.93 \%$, respectively with Pvr9-like protein 2 [Capsicum annuum]; CARGA3 and CARGA4 fragments had similar identity of $89.88 \%$ and $89.82 \%$ with TRGA15 [Capsicum annuum], while CARGA5, CARGA 9, CARGA10, CARGA11, and CARGA12 had $85.12 \%, 70.83 \%, 76.65 \%, 70.00 \%$ and $74.42 \%$ similarities with resistance protein $R G A 13$, respectively [Capsicum annuum] (Table 4).

Sequence homology analysis among 15 RGA fragments showed that the fragments are having varied amino acid similarities ranged from $44.4 \%$ to $87.5 \%$ (Table 5 ).

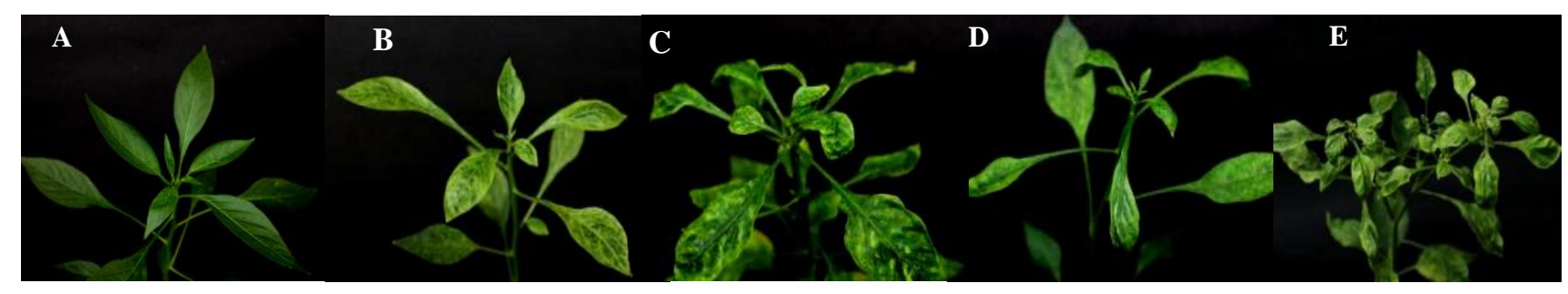

Figure 1. Symptoms appear on pepper plants: A. Healthy plant, B. Yellow leaves C. Yellow and curly leaves, D. Yellowing and bending upwards or downwards, E. Yellowing, curling, and bending upwards and/or downwards 
Identification and analysis of the motifs of RGA pepper protein and other plant- $R$ genes

The results of consensus analysis of amino acid prediction of the 15 fragments with NBS-LRR pepper plant protein and other plant $\mathrm{R}$ genes that had been deposited in Gene bank showed that NB-ARC had four conservative structures that were characteristic of the NBS region. The four conservative structures of amino acids were the Ploop/kinase-1a (GKTT) motif, kinase-2 (LVVLDDV), RNBS-B/kinase-3a (IILTTR), and hydrophobic amino acid (GLPL) (Figure 2). The amino acid length including the Ploop region to GLPL was 167 amino acids. The results of phylogenetic analysis of amino acids predicted sequences showed that $\mathrm{R}$ protein and the pepper NBS-LRR protein were divided into two groups, namely TNL-NBS and CNLNBS. All fragments obtained from this study along with proteins in other Solanaceae families and monocotyledons plants were as wheat, barley, rice, corn belonged to the CNL-NBS class, while the dicotyledons plants were included in the CNL-NBS class and TNL-NBS class (Figure 3).

\section{Grouping resistance responses}

The grouping of resistance responses based on DS value in 28 tested genotypes showed an even distribution from resistant to very susceptible group (Figure 4). Based on the disease severity (DS) value, the two genotypes namely, IPB C12 and F4-012328-6-3 could be classified as resistant $(0<\mathrm{DS}<20 \%)$ had $18.33 \%$ and $19.44 \%$ disease severity, respectively. There were 13 resistant genotypes (20<DS <40\%), five susceptible genotypes (40<DS $<60 \%$ ), and eight very susceptible genotypes (DS> 60\%).

Table 3. Genotype influence on incubation time, disease incident (DI) and disease severity (DS)

\begin{tabular}{llllllll}
\hline Genotypes & $\begin{array}{l}\text { Incubation } \\
\text { period (day) }\end{array}$ & DI $(\%)$ & DS $(\%)$ & Genotypes & $\begin{array}{l}\text { Incubation } \\
\text { period (day) }\end{array}$ & DI (\%) & DS $(\%)$ \\
\hline IPBC2 & $9-19$ & $93.33 \mathrm{a} * *)$ & $62.50 \mathrm{abc}$ & F4-012328-1AB-2 & $11-28$ & $40.00 \mathrm{cde}$ & $27.77 \mathrm{~d}$ \\
IPBC5 & $5-18$ & $86.67 \mathrm{a}$ & $62.77 \mathrm{abc}$ & F4-012328-6-3 & $11-28$ & $33.33 \mathrm{de}$ & $19.44 \mathrm{~d}$ \\
IPBC12 & $12-28$ & $20.00 \mathrm{e}$ & $18.33 \mathrm{~d}$ & F3-74 x Hot Chilli & $9-19$ & $73.33 \mathrm{ab}$ & $58.89 \mathrm{abc}$ \\
Gada & $10-26$ & $56.67 \mathrm{bc}$ & $32.78 \mathrm{~d}$ & F3-Elegance x 74-2 & $9-26$ & $46.67 \mathrm{~cd}$ & $26.66 \mathrm{~d}$ \\
Bara & $6-22$ & $90.00 \mathrm{a}$ & $54.16 \mathrm{bc}$ & F3-74 x Biola & $11-28$ & $40.00 \mathrm{cde}$ & $28.89 \mathrm{~d}$ \\
Genie & $10-27$ & $43.33 \mathrm{~cd}$ & $31.66 \mathrm{~d}$ & F7-160291-4-13-9-8-1 & $11-25$ & $36.67 \mathrm{cde}$ & $35.00 \mathrm{~d}$ \\
Giant & $10-27$ & $43.33 \mathrm{~cd}$ & $31.66 \mathrm{~d}$ & F7-145293-19-8-3-113-1 & $10-24$ & $40.00 \mathrm{cde}$ & $28.89 \mathrm{~d}$ \\
Ayesha & $11-25$ & $46.67 \mathrm{~cd}$ & $28.33 \mathrm{~d}$ & F7-145174-9-3-1-5-3 & $10-28$ & $36.67 \mathrm{cde}$ & $28.33 \mathrm{~d}$ \\
Seloka & $10-27$ & $50.00 \mathrm{~cd}$ & $31.11 \mathrm{~d}$ & F7-145291-14-9-3-12-1 & $8-20$ & $86.67 \mathrm{a}$ & $63.89 \mathrm{abc}$ \\
Yuni & $7-19$ & $73.33 \mathrm{ab}$ & $62.22 \mathrm{abc}$ & F7-145291-10-7-1-1-1-1 & $8-18$ & $73.33 \mathrm{ab}$ & $51.66 \mathrm{c}$ \\
SSP & $6-16$ & $83.33 \mathrm{a}$ & $57.50 \mathrm{abc}$ & F5-145291-14-9-3 & $7-20$ & $80.00 \mathrm{a}$ & $53.89 \mathrm{bc}$ \\
Anies & $11-26$ & $50.00 \mathrm{~cd}$ & $29.16 \mathrm{~d}$ & F7-1200005-141-16-2-9-4 & $6-19$ & $90.00 \mathrm{a}$ & $72.78 \mathrm{a}$ \\
Ungara & $10-25$ & $46.67 \mathrm{~cd}$ & $33.33 \mathrm{~d}$ & F7-1200005-120-7-1-7-8 & $6-15$ & $83.33 \mathrm{a}$ & $61.66 \mathrm{abc}$ \\
Seroja & $10-20$ & $90.00 \mathrm{a}$ & $71.11 \mathrm{ab}$ & F7-1200005-141-16-3-5-4 & $6-14$ & $86.67 \mathrm{a}$ & $60.00 \mathrm{abc}$ \\
\hline Not & &
\end{tabular}

Note: **) Different numbers followed by the letter reveals significant differences (Duncan test with the level of $5 \%$ ).

Table 4. Sequence identity among predicted amino acid sequence on pepper sample and resistance protein deposited from GenBank

\begin{tabular}{|c|c|c|c|c|c|c|}
\hline \multirow[b]{2}{*}{ NBS fragment } & \multirow[b]{2}{*}{ Genotype origin } & \multicolumn{5}{|c|}{$\begin{array}{r}\text { Accession on GenBank } \\
\end{array}$} \\
\hline & & $\begin{array}{c}\text { Pvr9-like protein } 2 \\
\text { [C. annuum }]\end{array}$ & $\begin{array}{c}\text { Begomovirus } \\
\text { resistance protein } \\
{[S \text {. lycopersicum }]}\end{array}$ & $\begin{array}{c}\text { White fly resistance } \\
\text { protein Mi-1,2 } \\
\text { [S. peruvianum }]\end{array}$ & $\begin{array}{c}\text { Resistance protein } \\
\text { RGA13 } \\
{[\text { C. annuum }]}\end{array}$ & $\begin{array}{c}\text { TRGA15 } \\
{[\text { C. annuum }]}\end{array}$ \\
\hline CARGA1 & IPB C12 & $60.34 \%$ & $58.19 \%$ & $72.41 \%$ & $65.66 \%$ & $64.88 \%$ \\
\hline CARGA2 & Gada & $81.71 \%$ & $53.30 \%$ & $67.43 \%$ & $69.28 \%$ & $69.64 \%$ \\
\hline CARGA3 & Genie & $67.61 \%$ & $52.51 \%$ & $71.02 \%$ & $87.43 \%$ & $89.88 \%$ \\
\hline CARGA4 & Giant & $66.48 \%$ & $53.04 \%$ & $72.73 \%$ & $87.43 \%$ & $89.82 \%$ \\
\hline CARGA5 & Anies & $66.47 \%$ & $51.18 \%$ & $71.86 \%$ & $85.12 \%$ & $83.33 \%$ \\
\hline CARGA6 & Ayesha & $83.53 \%$ & $50.00 \%$ & $66.47 \%$ & $63.86 \%$ & $65.06 \%$ \\
\hline CARGA7 & Seloka & $87.57 \%$ & $47.51 \%$ & $71.19 \%$ & $71.08 \%$ & $72.29 \%$ \\
\hline CARGA8 & Ungara & $79.44 \%$ & $50.81 \%$ & $72.22 \%$ & $77.11 \%$ & $77.11 \%$ \\
\hline CARGA9 & F4-012328-1AB-2 & $61.90 \%$ & $61.18 \%$ & $60.12 \%$ & $70.83 \%$ & $69.64 \%$ \\
\hline CARGA10 & F4-012328-6-3 & $61.40 \%$ & $60.11 \%$ & $68.05 \%$ & $76.65 \%$ & $74.40 \%$ \\
\hline CARGA11 & F3-Elegance x 74-2 & $55.03 \%$ & $56.40 \%$ & $58.58 \%$ & $70.00 \%$ & $67.65 \%$ \\
\hline CARGA12 & F3-74 x Biola & $58.43 \%$ & $59.02 \%$ & $64.20 \%$ & $74.42 \%$ & $73.84 \%$ \\
\hline CARGA13 & F7-160291-4-13-9-8-1 & $76.74 \%$ & $66.27 \%$ & $63.37 \%$ & $65.06 \%$ & $66.27 \%$ \\
\hline CARGA14 & F7-145293-19-8-3-113-1 & $92.05 \%$ & $41.77 \%$ & $71.59 \%$ & $73.49 \%$ & $74.70 \%$ \\
\hline CARGA15 & F7-145174-9-3-1-5-3 & $86.93 \%$ & $33.79 \%$ & $72.73 \%$ & $73.49 \%$ & $73.81 \%$ \\
\hline
\end{tabular}


Table 5. Homology (\%) among the predicted amino acid sequence of pepper samples

\begin{tabular}{|c|c|c|c|c|c|c|c|c|c|c|c|c|c|c|}
\hline CARGA1 & 100 & & & & & & & & & & & & & \\
\hline CARGA2 & 68.0 & 100 & & & & & & & & & & & & \\
\hline CARGA3 & 69.5 & 70.9 & 100 & & & & & & & & & & & \\
\hline CARGA4 & 65.3 & 69.5 & 87.5 & 100 & & & & & & & & & & \\
\hline CARGA5 & 73.7 & 64.7 & 80.4 & 82.2 & & & & & & & & & & \\
\hline CARGA6 & 61.1 & 82.1 & 65.9 & 63.7 & 100 & & & & & & & & & \\
\hline CARGA7 & 61.7 & 72.0 & 64.2 & 65.7 & 72.3 & 100 & & & & & & & & \\
\hline CARGA8 & 78.5 & 78.3 & 71.3 & 71.4 & 69.8 & 78.5 & 100 & & & & & & & \\
\hline CARGA9 & 59.9 & 60.9 & 61.9 & 68.9 & 50.0 & 60.0 & 71.3 & 100 & & & & & & \\
\hline CARGA10 & 60.4 & 63.4 & 65.8 & 71.9 & 53.7 & 60.4 & 68.9 & 74.4 & 100 & & & & & \\
\hline CARGA11 & 57.7 & 52.7 & 62.9 & 60.0 & 44.4 & 57.7 & 67.3 & 70.2 & 63.5 & 100 & & & & \\
\hline CARGA12 & 63.4 & 69.7 & 75.6 & 78.6 & 60.8 & 63.4 & 64.2 & 56.5 & 59.5 & 57.6 & 100 & & & \\
\hline CARGA13 & 80.8 & 69.4 & 63.9 & 60.5 & 64.1 & 80.8 & 74.7 & 51.2 & 62.6 & 60.4 & 66.7 & 100 & & \\
\hline CARGA14 & 84.2 & 80.0 & 69.0 & 69.7 & 77.4 & 84.2 & 79.2 & 60.7 & 61.9 & 57.7 & 61.3 & 76.7 & 100 & \\
\hline CARGA15 & 84.1 & 79.4 & 69.7 & 68.2 & 73.8 & 84.1 & 81.1 & 56.5 & 65.3 & 56.8 & 64.4 & 82.6 & 85.1 & 100 \\
\hline
\end{tabular}
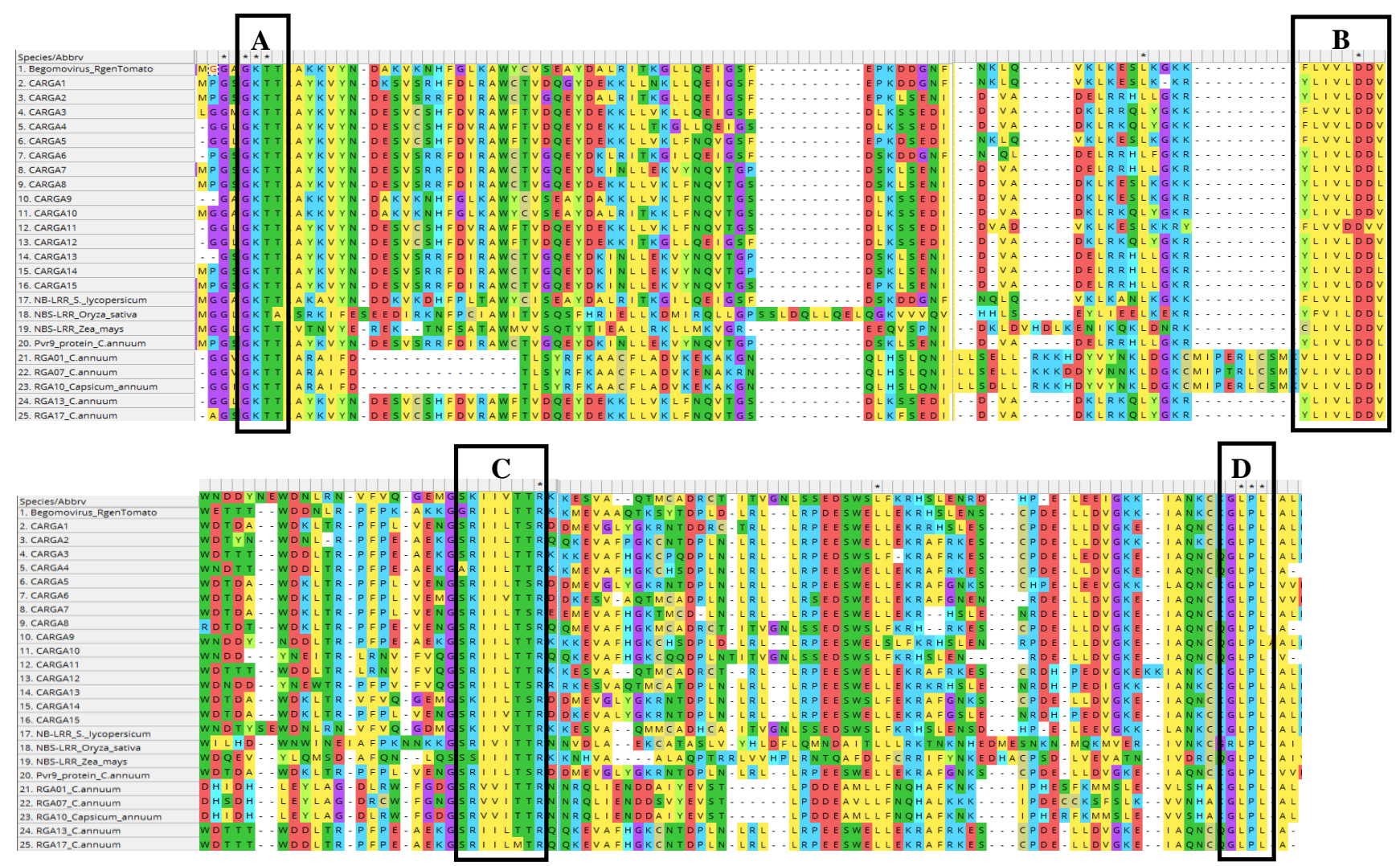

Figure 2. Alignment analysis of predicted amino acid (CARGA1-CARGA15) with several Solanaceae proteins on NBS site and R gene of other plans deposited on Genbank NCBI by MUSCLE method. Conserved domain areas are marked with bold line upon the sequence ( $\mathrm{A}=$ Ploop or kinase-1, B=kinase-2, $\mathrm{C}=\mathrm{RNBSB} /$ Kinase-3a, and $\mathrm{D}=$ hydrophobic domain or GLPL). 

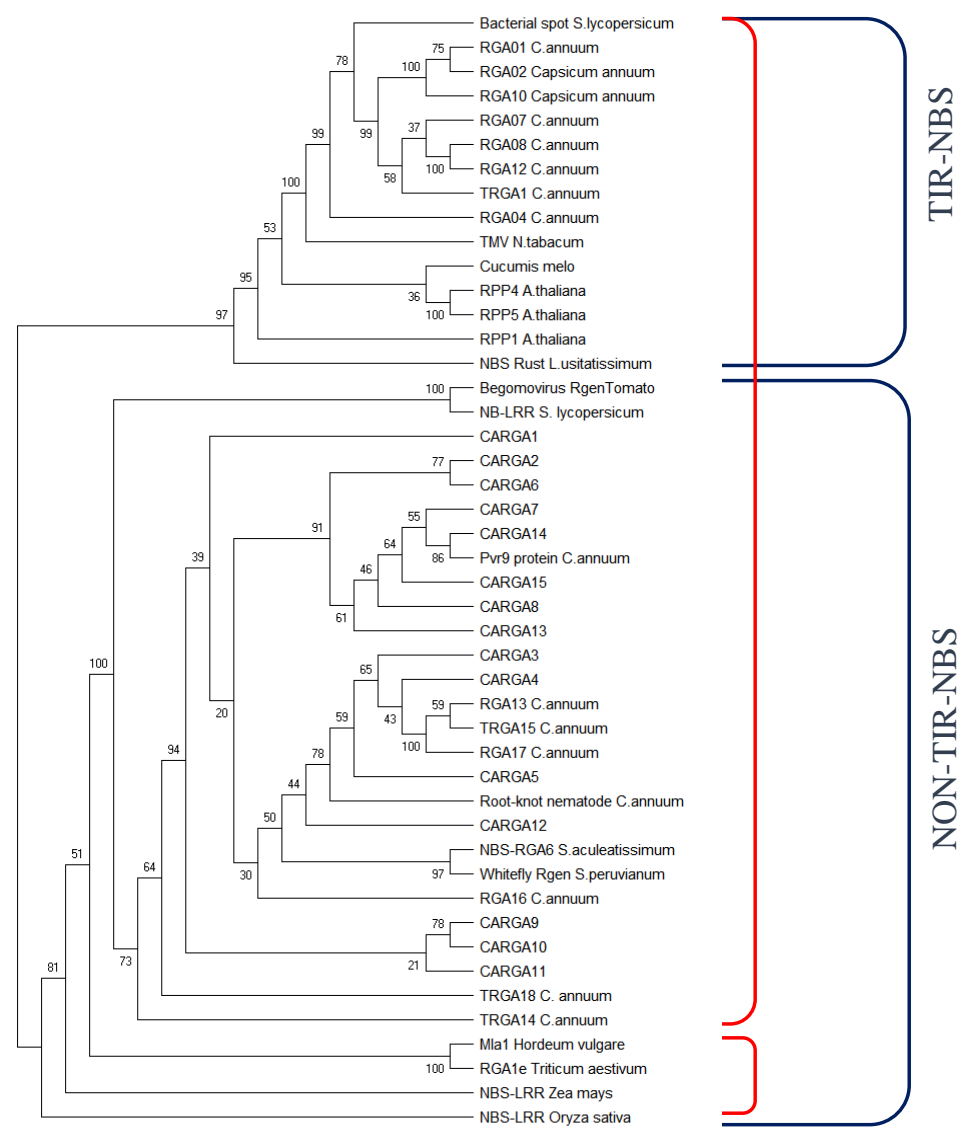

Figure 3. Phylogenetic tree of predicted amino acid sequences from pepper RGA (CARGA1-CARGA15) and several proteins from other plants based on MEGA X analysis and clustering due to NJ method by bootstrap 1000. M, Monocotyledons; D, Dicotyledons

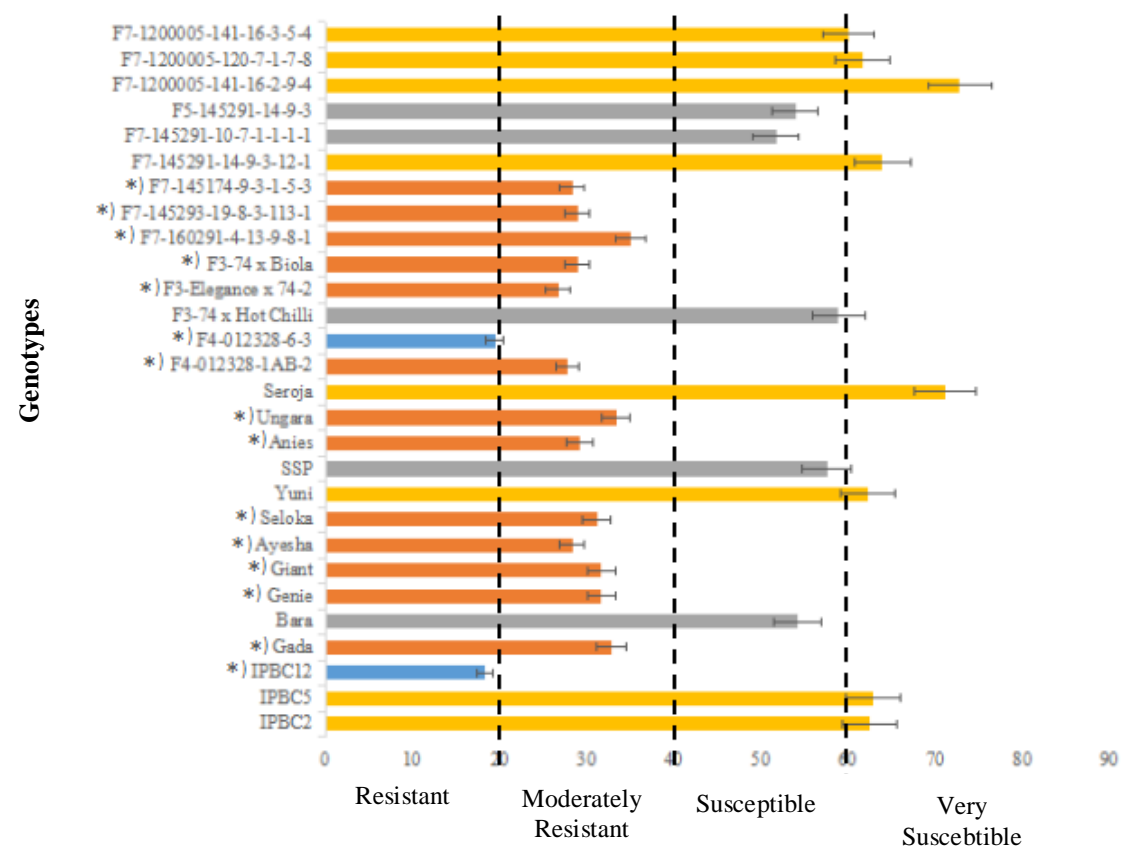

Severity disease $(\%)$

Figure 4. Grouping of resistance response to yellow leaf curl disease on 28 genotypes of pepper. The “*” marks the genotype that has the RGA fragment 


\section{Discussion}

The symptoms of pepper yellow leaf curl disease found in greenhouses are varied. Several factors that influence the variation of symptoms are pepper genotype, viral virulence, and environmental conditions, especially light intensity (Kenyon et al. 2014). All these environmental factors were also included in the present study. Thus, the varied results indicate high variability in the level of resistance to yellow leaf curl disease among the genotypes tested. The large variation among genotypes indicates the possibility of selection for resistance to this disease. Plants have succeeded in developing mechanisms for the recognition and protection of pathogens. Interactions between host and pathogen will trigger local and systemic responses including hypersensitive response (Balint-Kurti 2019). The NBS and LRR domains are generally associated with regulating the activity of the R-protein (Kourelis and Van der Hoorn 2018; Wang et al. 2015) which is the first defense of plant against attacks from pathogens.

In this study, 19 specific DNA fragments were successfully amplified from 28 samples of pepper DNA. From the 19 fragments, there were 15 fragments encoded by CARGA1-CARGA15 containing NBS areas with uninterrupted ORF. The results showed that there were 4 conservative structures of the NBS region. The four conservative structures of amino acids were the $\mathrm{P}$ loop/kinase-1a (GKTT), kinase-2 (LVVLDDV), RNBSB/kinase-3a (IILTTR), and hydrophobic amino acids (GLPL) (Tan et al. 2012). Nevertheless, not all motifs are required for function, such as rice $\mathrm{Pb} 1 \mathrm{CNL}$ protein, which lacks P-loop (Hayashi et al. 2010). The LRR domain protein works as detector against invading pathogens, either by direct interaction with the effectors released from pathogens, or by monitoring the status of host proteins targeted by the effectors. Due to recognition, the NBS domain would undergo conformational shift, ADP-bound state to an open ATP-bound state with exposed N-terminal domains to trigger hypersensitive reactions, finally causing apoptosis of infected cells to suppress the spread and proliferation of pathogen (Andersen et al. 2018).

The motif of kinase-1a/Ploop (GKTT), formed by several glycine residues $(\mathrm{G})$ and a fixed residue of lysine $(\mathrm{K})$, is involved in the phosphate binding of nucleotides. These motifs play a role in binding ATP to I-2 and M1 proteins from potato plants (Tameling et al. 2002). P-loop is also responsible in ATP-binding proteins involved with an ATP synthase ras protein, $\beta$ subunit, adenylate kinase with molecular switches and ribosomal elongation factor (Bahramnejad 2014). The same thing might also happen to the NBS protein. Motif kinase-2 (LVVLDDV) contains a fixed residue of aspartate (D) which coordinates the $\mathrm{Mg}^{2+}$ ions needed for the phosphotransferase reaction. Kinase3a/RNBSB (IILTTR) generally contains tyrosine (Y) or arginine $(\mathrm{R})$ which interacts with purine bases from ATP, while internal hydrophobic domains that have conserved motifs for GLPL has unknown function. However, seeing that its existence is highly conserved in the NBS-LRR class of the R-gene sequence, it is assumed that the domain has an important function related to the activity of the gene concerned (Jones et al. 2006). NBS-LRR are divided into two main subclasses, as CNL and TNL, and the distribution of NBS-LRR into these two subgroups is not comparable across different plant species (Jupe et al. 2012; Kang et al. 2012; Wan et al. 2013). CNL and TNL proteins are responsible for the recognition of specific pathogen (Collier et al. 2011). All fragments obtained from this study belong to the CNL. The absence of TNL not only occurs in pepper, but also has been reported in other monocotyledons plants like rice, wheat, maize, sorghum, and sugarcane (Jiang et al. 2020; Xu et al. 2018; Zhang et al. 2011). CARGA1 - CARGA15 fragments have high identical similarities with 5 types of proteins available in Genebank, namely whitefly resistance protein Mi-1,2 (Solanum peruvianum), Begomovirus resistance protein (Solanum lycopersicum), Pvr9-like protein 2 (Capsicum annuum), TRGA15 (Capsicum annuum), and Resistance protein RGA13 (Capsicum annuum) (Table 4). The five proteins encode successive resistance to whiteflies, begomovirus, potyvirus, late blight, and root-node nematodes. $\mathrm{R}$ proteins form a subclass of the signal transduction ATPases with numerous domains super family, class of molecular switch that are involved in various mechanisms, including immunity, apoptosis, and transcriptional regulation (Takken et al. 2012). This indicates that the 15 isolated NBS fragments may act as a resistance gene against some pests and diseases.

Information on grouping resistance responses is very important in plant breeding programs to determine the inheritance pattern of a trait. One of the assumptions that must be fulfilled to determine the inheritance pattern of a trait is that genes are more evenly spread among elders. 15 genotypes that have RGA fragments belong to the resistant and moderately resistant group, although they have a sequence identity for Begomovirus resistance protein (Solanum lycopersicum) ranging from only $33.79 \%$ $66.27 \%$, and they also have a sequence similarity of $58.58 \%-72.73 \%$ against whitefly resistance protein $\mathrm{Mi}-1,2$ (Solanum peruvianum) (Figure 4). It can be expected that whitefly and virus resistance interaction is highly linked (Zaidi et al. 2017).

Mi-1,2 protein provides resistance against phloemfeeding organisms such as whiteflies, aphids, psyllids and root-knot nematodes (Pallipparambil et al. 2014; Chen et al. 2015). Several possibilities have been hypothesized for the way $M i-1,2$ protein confers resistance in tomato, but the actual mechanisms remain unclear. $M i-1,2$ transcripts are present before insect attacks and resistance factors in $\mathrm{Mi}$ 1,2 are detected by $B$. tabaci early during the stylet penetration pathway, indicating that those factors might be present in the leaf epidermis, mesophyll layers, or both (Jiang et al. 2001). Those factors prevent the whiteflies from reaching phloem sieve elements. Nevertheless, once the stylets reach a sieve element, whiteflies behavior did not diverge between plants with or without the gene, thus, phloem appears to be equally acceptable to the whiteflies.

The interaction of Begomovirus resistance protein and whitefly resistance protein $\mathrm{Mi}-1,2$ is thought to activate the mechanism of plant resistance to yellow leaf curl infection in pepper, thus providing greater resistance compared to genotypes which do not have RGA. Based on the results of 
the present study, it is known that genotypes, namely IPB C12 and F4-012328-6-3 that contain RGA fragments have the potential to be resistant to PYLCD. Exploration related to RGA especially from various types of pepper genotypes in Indonesia, needs to be further developed. Several previous studies have succeeded in amplifying some RGA from pepper and their relatives (Wan et al. 2012; Naresh et al. 2017; Acquardo et al. 2020). The number of RGA with NBS-LRR from the identified pepper would be able to give an idea of the magnitude of the NBS family in pepper plants that can be exploited further in breeding programs.

\section{ACKNOWLEDGEMENTS}

This research was funded by the Ministry of Finance, the Republic of Indonesia through the LPDP scheme program and the Ministry of Research and Higher Education through the World Class Research Program. We thank the Center for Tropical Horticulture Studies and Virology Laboratory, Department of Plant Protection, IPB University for the support during the research.

\section{REFERENCES}

Acquadro A, Barchi L, Portis E. 2020. Whole genome resequencing of four Italian sweet pepper landraces provides insights on sequence variation in genes of agronomic value. Sci Rep 10:9189. DOI: 10.1038/s41598-020-66053-2

Al Shihi AAM. 2019. Geminivirus Occurrence in Australia, China, Europe, and the Middle Eastern Countries. In: Kumar RV (eds) Geminiviruses: Impact, Challenges and Approaches. Springer International Publishing: Cham.

Andersen E, Ali S, Byamukama E, Yen Y, Nepal M. 2018. Disease resistance mechanisms in plants. Genes 9 (7): 339. DOI: 10.3390/genes9070339

Annisaa N, Hidayat P, Giyanto, Hidayat SH, Lee S. 2021. Multiple infections of Begomovirus on its host plants. IOP Conference Series: Earth and Environmental Science 694: 012047. DOI: 10.1088/17551315/694/1/012047

Bahramnejad B. 2014. Identification and characterization of a NBS-LRR class resistance gene analog in Pistacia atlantica subsp. Kurdica Mol Biol Res Comms 3 (3): 175-185.

Balint-Kurti P. 2019. The plant hypersensitive response: Concepts, control and consequences. Mol plant pathol 20 (8): 1163-1178. DOI: $10.1111 / \mathrm{mpp} .12821$

Barboza N, Blanco-Meneses M, Esker P, Moriones E, Inoue-Nagata AK. 2018. Distribution and diversity of begomoviruses in tomato and sweet pepper plants in Costa Rica. Ann Appl Biol 172: 20-32. DOI: 10.1111/aab.12398

Bosland PW, Votava EJ, Votava EM. 2012. Peppers: Vegetable and spice capsicums (2nd edn). CABI Publishing, Cambridge.

Calvo FJ, Bolckmans K, Belda JE. 2009. Development of a biological control-based Integrated Pest Management method for Bemisia tabaci for protected sweet pepper crops. Ento Exp Appl 133: 9-18. DOI: 10.1111/j.1570-7458.2009.00896.x

Caplan J, Padmanabhan M, Dinesh-Kumar SP. 2008. Plant NB-LRR immune receptors: from recognition to transcriptional reprogramming. Cell Host Microbe 3: 126-135 DOI: 10.1016/j.chom.2008.02.010

Chen HM, Lin CY, Yoshida M, Hanson P, Schafleitner R. 2015 Multiplex PCR for detection of tomato yellow leaf curl disease and root-knot nematode resistance genes in tomato (Solanum lycopersicum L.). Int J Plant Breed Genet 9: 44-56. DOI: 10.3923/ijpbg.2015.44.56

Collier SM, Hamel LP, Moffett P. 2011. Cell death mediated by the Nterminal domains of a unique and highly conserved class of NB-LRR protein. Mol Plant-Microbe Interact 24 (8): 918-931. DOI: 10.1094/mpmi-03-11-0050

De Barro PJ, Hidayat SH, Frohlich D, Subandiyah S, Ueda S. 2008. A virus and its vector, pepper yellow leaf curl virus and Bemisia tabaci, two new invaders of Indonesia. Biol Invas10: 411-433. DOI: 10.1007/s10530-007-9141-x

Ellango R, Singh ST, Rana VS, Gayatri PN, Raina H, Chaubey R, Naveen NC, Mahmood R, Ramamurthy VV, Asokan R. 2015. Distribution of Bemisia tabaci genetic groups in India. Environ Entomol 44: 12581264. DOI: $10.1093 / \mathrm{ee} / \mathrm{nvv062}$

Fadhila C, Lal A, Vo TTB, Ho PT, Hidayat SH, Lee J, Kil EJ, Lee S. 2020. The threat of seed-transmissible pepper yellow leaf curl Indonesia virus in chili pepper. Microbial Pathogen 143: 104132. DOI: $10.1016 /$ j.micpath.2020.104132

Firdaus S, Vosman B, Hidayati N, Supena EDJ, Visser RGF, van Heusden AW. 2013. The Bemisia tabaci species complex: Additions from different parts of the world. Insect Sci 20 (6): 723-733 DOI: 10.1111/1744-7917.1200

Ghanim M. 2014. A review of the mechanisms and components that determine the transmission efficiency of tomato yellow leaf curl virus (Geminiviridae; Begomovirus) by its whitefly vector. Virus Res 186: 47-54. DOI: 10.1016/j.virusres.2014.01.022

Gilbertson RL, Batuman O, Webster CG, Adkins S. 2015. Role of the insect supervectors Bemisia tabaci and Frankliniella occidentalis in the emergence and global spread of plant viruses. Annu Rev Virol 2: 67-93. DOI: 10.1146/annurev-virology-031413-085410

Hayashi N, Inoue H, Kato T, Funao T, Shirota M, Shimizu T, Kanamori H, Yamane H, Hayano-Saito Y, Matsumoto T. 2010. Durable panicle blast-resistance gene $\mathrm{Pb} 1$ encodes an atypical CC-NBS-LRR protein and was generated by acquiring a promoter through local genome duplication. Plant 64: 498-510. DOI: 10.1111/j.1365313X.2010.04348.x

Horowitz AT, Antigua Y, Gerling D. 2011. Management of Bemisia tabaci whiteflies. In The Whitefly, Bemisia tabaci (Homoptera: Aleyrodidae) Interaction with Geminivirus-Infected Host Plants. Springer 2011: 293-322. DOI: 10.1007/978-94-007-1524-0_11

Islam W, Akutse KS, Qasim M, Khan KA, Ghramh HA, Idrees A, Latif S. 2018. Bemisia tabaci mediated facilitation in diversity of begomoviruses: Evidence from recent molecular studies. Microb Pathogen 123: 162-168. DOI:10.1016/j.micpath.2018.07.008

Jiang Y, Nombela G, Muñiz M. 2001. Analysis by DC-EPG of the resistance to Bemisia tabaci on an Mi-tomato line. Entomologia Experimentalis et Applicata 99: 295-302. DOI: 10.1023/A:1019240418595

Jiang G, Liu D, Yin D, Li C, Zhu L, Zhai W. 2020. A Rice NBSARC gene conferring quantitative resistance to bacterial blight is regulated by a pathogen effector-inducible miRNA. Mol Plant 13 (12): 1752-1767. DOI: 10.1016/j.molp.2020.09.015

Jones JD, Dangl JL. 2006. The plant immune system. Nature 444: $323-$ 329. DOI:10.1038/nature05286.

Jupe F, Pritchard L, Etherington GJ, MacKenzie K, Cock PJA, Wright F, Sharma SK, Bolser D, Bryan GJ, Jones JDG. 2012. Identification and localisation of the NB-LRR gene family within the potato genome. BMC Genomics 13: 75. DOI: 10.1186/1471-2164-13-75

Kang YJ, Kim KH, Shim S, Yoon MY, Sun S, Kim MY, Van K, Lee SH. 2012. Genome-wide mapping of NBS-LRR genes and their association with disease resistance in soybean. BMC Plant Biol 12: 139. DOI: $10.1186 / 1471-2229-12-139$

Kenyon L, Kumar S, Tsai WS, Hughes Jd. 2014. A. Chapter Six - Virus Diseases of Peppers (Capsicum spp.) and Their Control. In: Loebenstein, G Katis, N (eds) Advances in Virus Research. Academic Press.

Kenyon L, Tsai WS, Shih SL, Lee LM. 2014. Emergence and diversity of begomoviruses infecting solanaceous crops in East and Southeast Asia. Virus Res 186: 104-113. DOI: 10.1016/j.virusres.2013.12.026

Koeda S, Homma K, Tanaka Y, Onizaki D, Kesumawati E, Zakaria S, Kanzaki S. 2018. Inoculation of Capsicums with pepper yellow leaf curl Indonesia virus by combining agroinoculation and grafting. Hortic J 87: 364-371. DOI: 10.2503/hortj.OKD-137

Kourelis J, Van der Hoorn RAL. 2018. Defended to the nines: 25 years of resistance gene cloning identifies nine mechanisms for $\mathrm{R}$ protein function. Plant Cell 30: 285-299. DOI: 10.1105/tpc.17.00579

Kushwaha N, Singh AK, Basu S, Chakraborty S. 2015. Differential response of diverse solanaceous hosts to tomato leaf curl New Delhi virus infection indicates coordinated action of NBS-LRR and RNAi- 
mediated host defense. Archiv Virol 160: 1499-1509. DOI: 10.1007/s00705-015-2399-x

Milenovic M, Wosula EN, Rapisarda C, Legg JP. 2019. Impact of host plant species and whitefly species on feeding behavior of Bemisia tabaci. Front Plant Sci 10: 1. DOI: 10.3389/fpls.2019.00001

Naresh P, Reddy MK, Reddy AC, Lavanya B, Reddy DL, Reddy KM. 2017. Isolation, characterization and genetic diversity of NBS-LRR class disease-resistant gene analogs in multiple virus resistant line of chilli (Capsicum annuum L.). 3 Biotech 7 (2): 114. DOI: 10.1007/s13205-017-0720-y

Olatunji TL, Afolayan AJ. 2018. The suitability of chili pepper (Capsicum аппиит $\mathrm{L}$.) for alleviating human micronutrient dietary deficiencies: A review. Food Sci Nutr 6: 2239-2251. DOI: 10.1002/fsn3.790

Ouattara A, Tiendrébéogo F, Lefeuvre P, Hoareau M, Claverie S, Allibert A, Chiroleu F, Traoré EV, Barro N, Traoré O. 2020. Diversity, distribution and prevalence of vegetable-infecting geminiviruses in Burkina Faso. Plant Pathol 69: 379-392. DOI: 10.1111/ppa.13120

Pallipparambil GR, Sayler RJ, Shapiro JP, Thomas JMG, Kring TJ. 2014 Mi-1.2, an R gene for aphid resistance in tomato, has direct negative effects on a zoophytophagous biocontrol agent, Orius insidiosus. J Exp Bot 66: 549-557. DOI:10.1093/jxb/eru361

Pandey V, Srivastava A, Gaur RK. 2021. Begomovirus: A curse for the agricultural crops. Archiv Phytopathol Plant Protect 54: 949-978. DOI: $10.1080 / 03235408.2020 .1868909$

Soesanto L, Fatihah B, Manan A, Prihatiningsih N. 2020. Organic control of Bemisia tabaci Genn. on Capsicum annuum with entomopathogenic fungi raw secondary metabolites. Biodiversitas 21: 5786-5791. DOI: 10.13057/biodiv/d211240

Takken FW, Goverse A. 2012. How to build a pathogen detector: Structural basis of NB-LRR function. Curr Opin Plant Biol 15: 1-10 DOI: 10.1016/j.pbi.2012.05.001

Tameling WIL, Elzinga SDJ, Darmin PS, Vossen JH, Takken FLW, Haring MA, Cornelissen BJC. 2002. The tomato R gene products I-2 and Mi-1 are functional ATP binding proteins with ATPase activity. Plant Cell 14: 2929-2939. DOI: 10.1105/tpc.005793
Tan S, Wu S. 2012. Genome wide analysis of nucleotide-binding site disease resistance genes in Brachypodium distachyon. Comp Funct Genomics 2012: 418208. DOI: 10.1155/2012/418208

Tripodi P, Kumar S. 2019. The Capsicum Crop: An Introduction. In: Ramchiary N, Kole C (eds). The Capsicum Genome. Springer International Publishing: Cham.

Wan H, Yuan W, Bo K, Shen J, Pang X, Chen J. 2013. Genome-wide analysis of NBS-encoding disease resistance in Cucumis sativus and phylogenetic study of NBS-encoding genes in Cucurbitaceae crops. BMC Genomics 14: 109. DOI: 10.1186/1471-2164-14-109

Wang GF, Ji J, Ei-Kasmi F, Dangl JL, Johal G, Balint-Kurti PJ. 2015. Molecular and functional analyses of a maize autoactive NB-LRR protein identify precise structural requirements for activity. PLoS Pathog 11: e1004674. DOI: 10.1371/journal.ppat.1004674

Wei J, He YZ, Guo Q, Guo T, Liu YQ, Zhou XP, Liu SS, Wang XW 2017. Vector development and vitellogenin determine the transovarial transmission of begomoviruses. Proceedings of the National Academy of Sciences 114: 6746-6751. DOI: 10.1073/pnas.1701720114

Xu Y, Liu F, Zhu S, Li X.2018. The maize NBS-LRR gene ZmNBS25 enhances disease resistance in rice and Arabidopsis. Front Plant Sci 9: 1033. DOI: $10.3389 /$ fpls.2018.01033

Yamaguchi H, Ohnishi J, Saito A, Ohyama A, Nunome T, Miyatake K, Fukuoka H. 2018. An NB-LRR gene, TYNBS1, is responsible for resistance mediated by the Ty-2 Begomovirus resistance locus of tomato. Theor Appl Genet 131: 1345-1362. DOI: 10.1007/s00122018-3082-X

Yang X, Zhang L, Yang Y, Schmid M, Wang Y. 2021. miRNA mediated regulation and interaction between plants and pathogens. Int $\mathrm{J}$ Mol Sci 22: 2913. DOI: 10.3390/ijms22062913

Zaidi SSA, Briddon RW, Mansoor S. 2017. Engineering dual Begomovirus-Bemisia tabaci resistance in plants. Trends Plant Sci 22: 6-8. DOI: 10.1016/j.tplants.2016.11.005

Zhang N, Wang S, Wang, H, Liu D. 2011. Isolation and characterization of NBS-LRR class resistance homologous gene from wheat. Agric Sci China 10: 1151-1158. DOI: 10.1016/S1671-2927(11)60105-3 